R A X I S ・IIによる回折データの収集

\title{
O東常行 杵㴊隆男（理学電機）
}

X 線検出器としてイメージングブレート（I P )を利用する振動カメラR A X I S - II C が新 たに開発された”ので、これによるX線回折デー夕収集について報告する。既に報告されて いるIPを用いたテータ収集システム2゙とは、IPの読み出し機栱やソフトウェア等に於て 若千異なっている。

[ソフトウェア]ブログラムの棈成は次の通りである。1）静止喚から結晶方位の決定及び 精密化(STILL)。2）振動像から䅡分反射強度の決定(OSCILL)。3) フレームスケールの決定 及び 1 組の独立な㩰造因子の出力(SCALE)。4) 回折バターンのグラフィック表示(PLOT)。格 子定数眠知の蛋白留轺晶では自䡃的に結晶方位が決定される゙うた、結晶の軸立を行わなく てもテータ収集は可能である。䅡分反射強度は通常Rossmannタイブのブロファイルフィッテ イング法により見皘られる。部分反射については、2枚の連続するフレームでの強度を加え 合わせて穔分反射強度とする。暴常分散效果の解析やいわゆるボストリファイメントも可能 である。全ての計算はVAX3100ワークステーションで行われる。

[测定・処理例]卵白リソチーム（正方晶、 $P 4_{3} 2,2, a=79.1, c=37.9 \AA$ ）の $2.0 \AA$ 分解能の回折 像を次の条件で撮影した。グラファイトモノクロメータで単色化したCuK $\alpha(40 \mathrm{kV}, 100 \mathrm{~mA}) 、$ 結

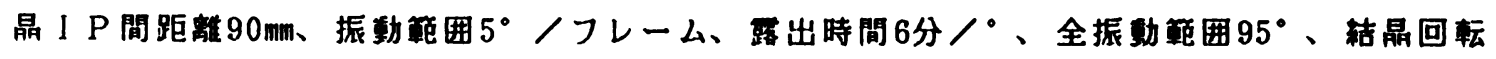
軸とa*軸との傾き約 $13^{\circ}$ 。2枚の静止像から自動的に結晶方位を決定し、振動像19フレーム から1> $\sigma(1)$ の 35760 個の植分反射強度を得た。これをスケール後同洒な反射を平均し、最終

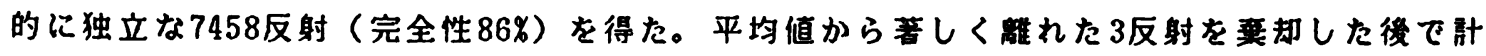

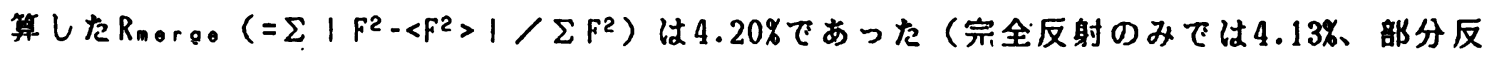
射のみでは4.76\%)。

以上の結果から、少なくとも統計的な評洒の上では、RAXIS-IICにより良質な回折データか 収集出来ること汃解る。なお、異常分散効果の测定例やボストリファイメントについては、 当日ボスター展示する。

1）坂出政隆、大沢登、宗像広志、佐々木智寿、宗川縏、杵㴊隆男、柴出淳（1990） 日本結昆学会㜔演要旨集

2) Tanaka, I., Yao, M., Suzuki, M., Hikichi, K., Matsumoto, T., Kozasa, M. and Katayama, C. (1990) J. Appl. Cryst. 23, 334-339.

3) Higashi, T. (1990) J. Appl. Cryst. 23, 253-257. 